\title{
Educational Challenges in Shaping the Entrepreneurship of IT Students
}

\begin{abstract}
One of the key success factors in the IT industry is innovation. It is an integral part of this industry and determines its development and, in addition, there are clear links between innovation and entrepreneurship. Entrepreneurship in the IT industry is of significant economic and social importance as it currently affects virtually every sphere of our lives. This means huge challenges for the education system in the field of entrepreneurship education among future IT specialists. The aim of the article is to analyze entrepreneurial attitudes among IT students, as well as to identify opportunities and barriers to entrepreneurship development in the IT industry in the context of educational challenges. The author formulated the following main research issue: What are the educational challenges in the field of entrepreneurship of IT students? In the research, a survey questionnaire was used for IT students at the Pedagogical University of Krakow. Research has shown that in IT studies, the importance of shaping soft competences, which are necessary for running a business, are largely omitted. They should build confidence, which is very important for people who would like to start their business however are afraid of failure, and it is the main barrier to entrepreneurship development in the IT industry. Creative activities that stimulate business ideas also play an important role in educating entrepreneurship in IT students.
\end{abstract}

Keywords: academic entrepreneurship; education of entrepreneurship; entrepreneurship of IT students; soft skills of IT students; students of computer science

Received: 10 June 2019

Accepted: 11 May 2020

\section{Suggested citation:}

Lupa-Wójcik, I. (2020). Educational Challenges in Shaping the Entrepreneurship of IT Students. Przedsiębiorczość - Edukacja [Entrepreneurship - Education], 16(1), 119-131. doi: $10.24917 / 20833296.161 .10$

\section{Introduction}

Entrepreneurship in the IT industry is of significant economic and social importance as it currently affects virtually every sphere of our lives. This means huge challenges for the 
education system in the field of entrepreneurship education among future IT specialists. IT students often have very well-developed hard skills (technical, programming, engineering skills, etc.). They also have a lot of business ideas. However, as their education overlooks the importance of shaping soft skills as well as marketing competences, they often cannot sell their ideas adequately. They lack confidence and determination and have poor negotiating skills. This largely contributes to failures in running their own businesses.

The aim of the article is to analyze entrepreneurial attitudes among IT students, as well as to identify opportunities and barriers to entrepreneurship development in the IT industry in the context of educational challenges.

The article consists of four parts. The first is a literature review of the subject, the second is the research methodology while the last two are a presentation of research results and conclusions.

\section{Literature review}

The problem of the entrepreneurship education of students has been widely described in the literature (see Henry, Hill, Leitch, 2005; Higgins, Elliott, 2011; Kuratko, 2005; Oosterbeek, Van Praag, Ijsselstein, 2010; Peterman, Kennedy, 2003; Rasmussen, Sørheim, 2006; Vesper, Gartner, 1997; Wilson, Kickul, Marlino, 2007). Many authors have also undertaken to study the entrepreneurship education of students of engineering majors, including IT students (see Lüthje, Franke, 2003; Soares et al., 2013; Souitaris, Zerbinati, Al-Laham, 2007). For example, a new line of project-based learning in the School of Engineering of University of Minho (Innovation and Entrepreneurship Integrated Project (IEIP)) was presented by Soares, et al. (2013). Importantly for this article, in the described project students had the opportunity to shape not only hard but soft skills, including marketing (e.g. project management, teamwork, communication ability and personal development).

In Poland, research on supporting academic entrepreneurship in the IT industry has been conducted, among others, by M. Niedźwiedziński, H. Klepacz and K. Szymańska (2016). An interesting project was also described by P. Milczarski (2015) concerning the entrepreneurship education of IT students by the University of Lodz in cooperation with CIAT (Innovation Center Technological Accelerator). CIAT is a venture fund that organized several entrepreneurship workshops in 2013-2014 for students and postgraduate students. Among the topics were public speeches, creating a business plan for acquiring funding, practical aspects of creating and using intellectual properties, creating mobile games: from idea to financing, and ICT projects: integration of services and mobile applications. The main idea of the project was "to show the participants how can they transfer their ideas from different fields into projects that can apply for funding/financing" (Milczarski, 2015: 82). As it turns out, games can be extremely useful in the education of entrepreneurship of IT students. This is mentioned, among others, F. Bellotti, R. Berta, A. De Gloria, E. Lavagnino, F.M. Dagnino, M. Ott, I.S. Mayer (2012); F. Bellotti, R. Berta, A. De Gloria, E. Lavagnino, E. Antonaci, F.M. Dagnino, M. Ott (2013); D. La Guardia, M. Gentile, V. Dal Grande, S. Ottaviano, M. Allegra (2014). Games can also be useful in shaping the soft skills of IT students. In the report Employee of the Future (Infuture Hatalska Foresight Institute, 2019), the authors draw attention to the need to combine hard skills with soft skills including knowledge in the fields of psychology and sociology, because only soft skills distinguish us from machines and artificial intelligence and in 
this, we as humans are best. As Amar Kuman from Harvard Business School said: "Being a great programmer, you will get a job in 2018. But to stay up to 2030, more and more soft skills are needed" (Infuture Hatalska Foresight Institute, 2019). This also applies to future entrepreneurs who want to gain new markets. Among the competences of the future, such features as the ability to actively learn, creativity (understood very broadly as a domain not only artistic but also technological, abstract thinking connecting different parts of our experience), to share knowledge with others and to cooperate with others or an attitude towards solving problems are given (Infuture Hatalska Foresight Institute, 2019). It seems that these are basic challenges in the education of entrepreneurship of IT students: shaping creativity, abstract thinking, the ability to cooperate with others, negotiation and marketing skills (in the field of sales as well).

\section{Methodology}

The aim of the research was to analyze entrepreneurial attitudes among IT students, as well as to identify opportunities and barriers to entrepreneurship development in the IT industry in the context of educational challenges.

The author formulated the following main research issue: What are the educational challenges in the field of entrepreneurship of IT students? She also highlighted the following specific questions:

- What are the attitudes of IT students towards setting up their own business?

- What opportunities and barriers do IT students see regarding starting and running their own business?

Figure 1 . Surveyed students by year of study

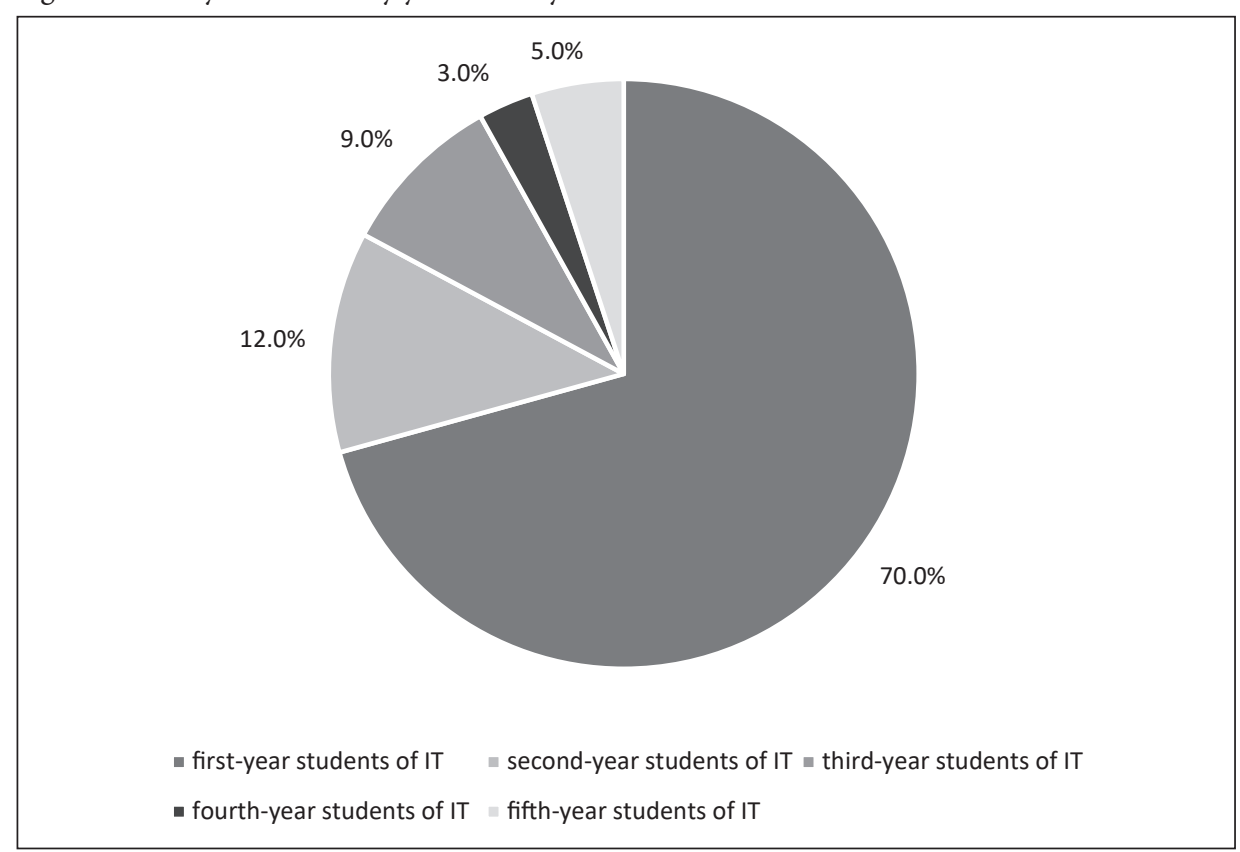

Source: author 
- What skills should be developed among IT students to increase their entrepreneurship? To answer the formulated research questions the author applied a survey to IT students as the research method. The research was carried out in the months of JanuaryMarch 2019 among the IT students at the Pedagogical University of Krakow. The questionnaire was sent in an electronic form consisting of 14 questions regarding the attitude of respondents to the entrepreneurship of IT students. In addition, the questionnaire contained three questions about gender, age and place of residence of the respondents. A total of 166 students completed the survey, of which 116 were first-year IT (70\%), 20 were second-year (12\%) and 15 were third-year (9\%) (Figure 1). The respondents were mainly male (80\%) aged $21-23$ (49\%), 20 or less (29\%), and 24-26 (16\%). It is important that $40 \%$ of respondents live in a provincial town, and $36 \%$ are from a village.

\section{Findings}

Investigating the educational challenges in shaping entrepreneurship for IT students requires researching entrepreneurial attitudes among these students in the first place. The results from this part of the research are presented in Figure 1 (entrepreneurial features of the surveyed students) and Figure 2 (features hindering entrepreneurship surveyed students).

As the research shows, $74 \%$ of surveyed students like to make changes and improvements in the company, $71 \%$ after doing a good job often have the feeling that they could do it even better, and $70 \%$ feel bad when they feel that they are wasting their time. In addition, $67 \%$ prefer to work with a person who is difficult but well-versed in the subject, rather than consistent but incompetent. Most respondents definitely do not want to be told what to do (58\%). Every second student likes risk and new challenges (53\%), thinks $\mathrm{s} /$ he is always organized and plans ahead (52\%) and always knows what $\mathrm{s} / \mathrm{he}$ wants and tries to do it $(45 \%)$.

It turns out that features that facilitate entrepreneurship among IT students are more than those that impede it. From Figure 3 we can read that only $29 \%$ of respondents prefer to live in peace than to constantly search for and follow new goals, $31 \%$ can do monotonous work without feeling bored, 34\% like working in an 8-hour mode, and $40 \%$ have a lot of business ideas but do not have enough determination.

The research results show that the surveyed students are dominated by entrepreneurial features. They are creative, have lots of ideas and huge potential. This shows that the direction of their attitudes towards entrepreneurship resulting in more interest in self-employment in the future. This could have very beneficial effects on the development of the IT industry and the entire economy.

Students were asked if they plan to open their own businesses. It turns out that $46 \%$ of respondents plan to set up a company in the future, $5 \%$ do not exclude the possibility, $2 \%$ currently run own business, and $2 \%$ have run one in the past. This means that at least half of the surveyed students plan to open a business in the future. Students are therefore aware of their entrepreneurial features and would like to use them in practice in the future.

However, students are aware of the risks associated with starting their own business, mainly due to uncertainty about earnings. Running a business means the need to constantly attract customers to ensure survival and profit. Risk and uncertainty about income are the basic factors that hold back IT students before establishing their own company (75\%). 
Figure 2. Entrepreneurial features of the surveyed students

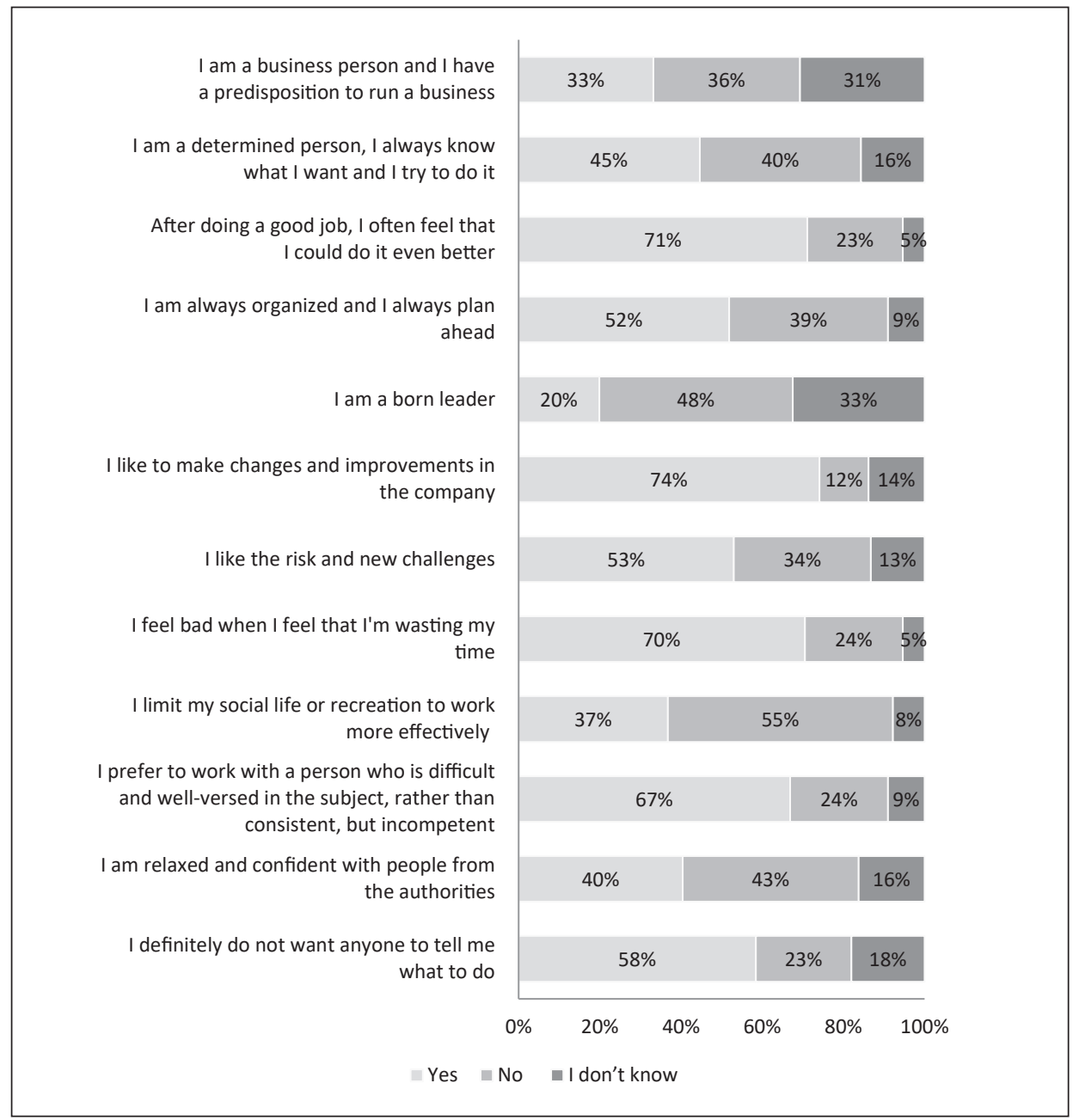

Source: author

Moreover IT students often have no business ideas (62\%) and they are afraid that they do not have adequate knowledge or qualifications in the field of entrepreneurship (51\%). Some of them also have problems with the commercialization of their ideas (30\%) (Figure 4).

According to the respondents, people who achieve success in the IT industry owe it primarily to their personality (creativity and determination) (68\%), an innovative idea (61\%), and their skills (e.g. technical, organizing, negotiating, etc.) (52\%) (Figure 5). This shows that IT students understand the importance of soft competencies in achieving business success. In the first place, they put creativity and determination, but along with the ability to generate innovative ideas. They also appreciate the ability to negotiate. Other factors (including hard competences) are also important, however to a slightly less extent.

The earliest stage of a company's development is the start-up. This is a situation where the company is not yet able to earn its living. Therefore start-ups can be defined as young 
Figure 3. Features hindering entrepreneurship among surveyed students

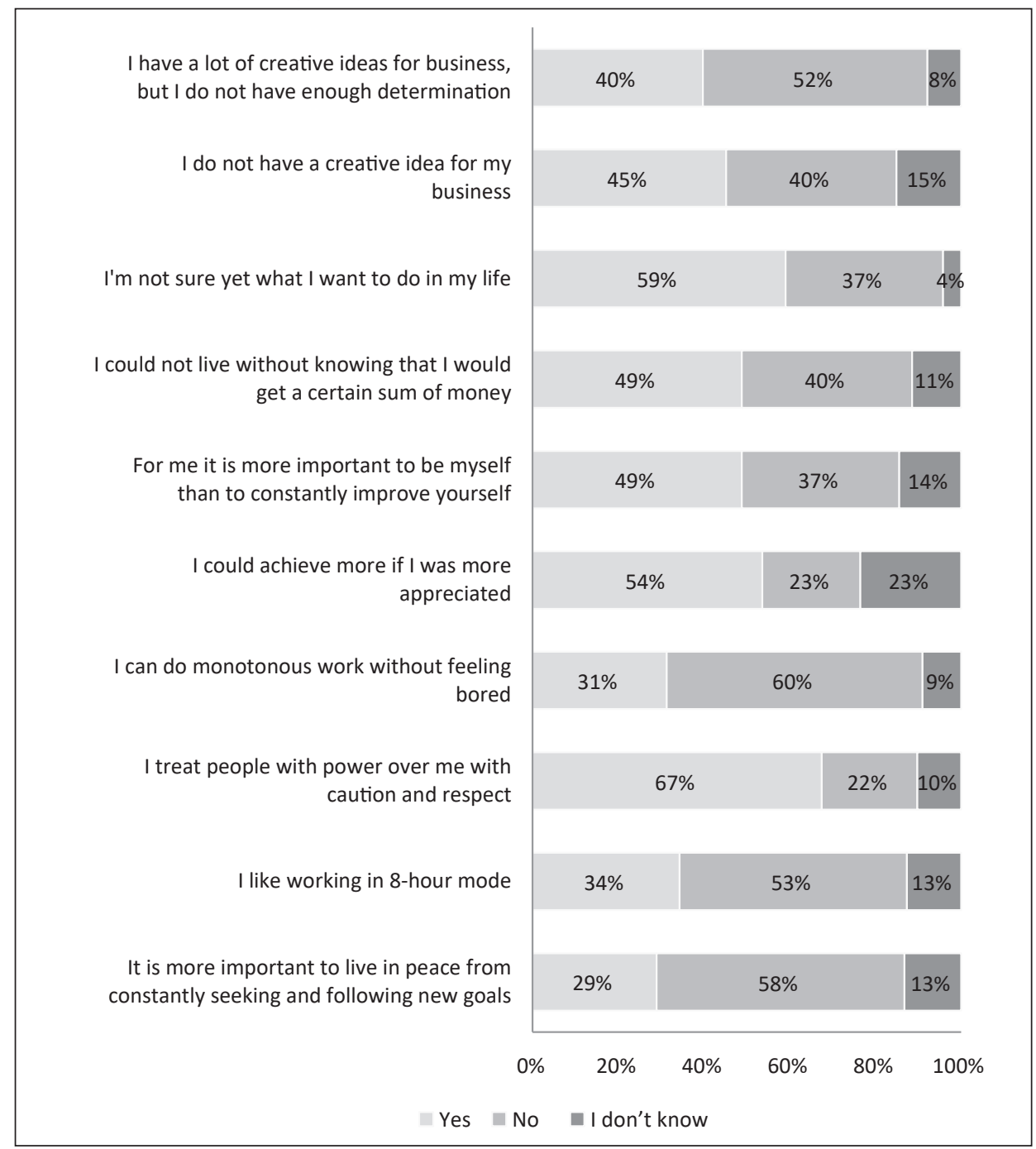

Source: author

companies seeking a business model. In practice, many of them fail before moving on to the next level. In the opinion of respondents, start-ups in the IT industry fail mainly due to the lack of business experience of their founders (55\%) and a lack of customers (50\%), as well as insufficient soft skills, e.g. negotiations (42\%) (Figure 6). Students note that the lack of soft skills can affect the failure of start-ups. The most important role in acquiring new customers is played by marketing and sales skills, including establishing interpersonal relationships and the ability to properly present the benefits of purchasing a given product or conducting business negotiations. The presented research results lead to the conclusion that students are afraid that they do not have sufficient soft skills (also marketing) to acquire customers and thus remain in the market. 
Figure 4 . The three most important reasons for the lack of an intention to start a company by students in the IT industry in Poland

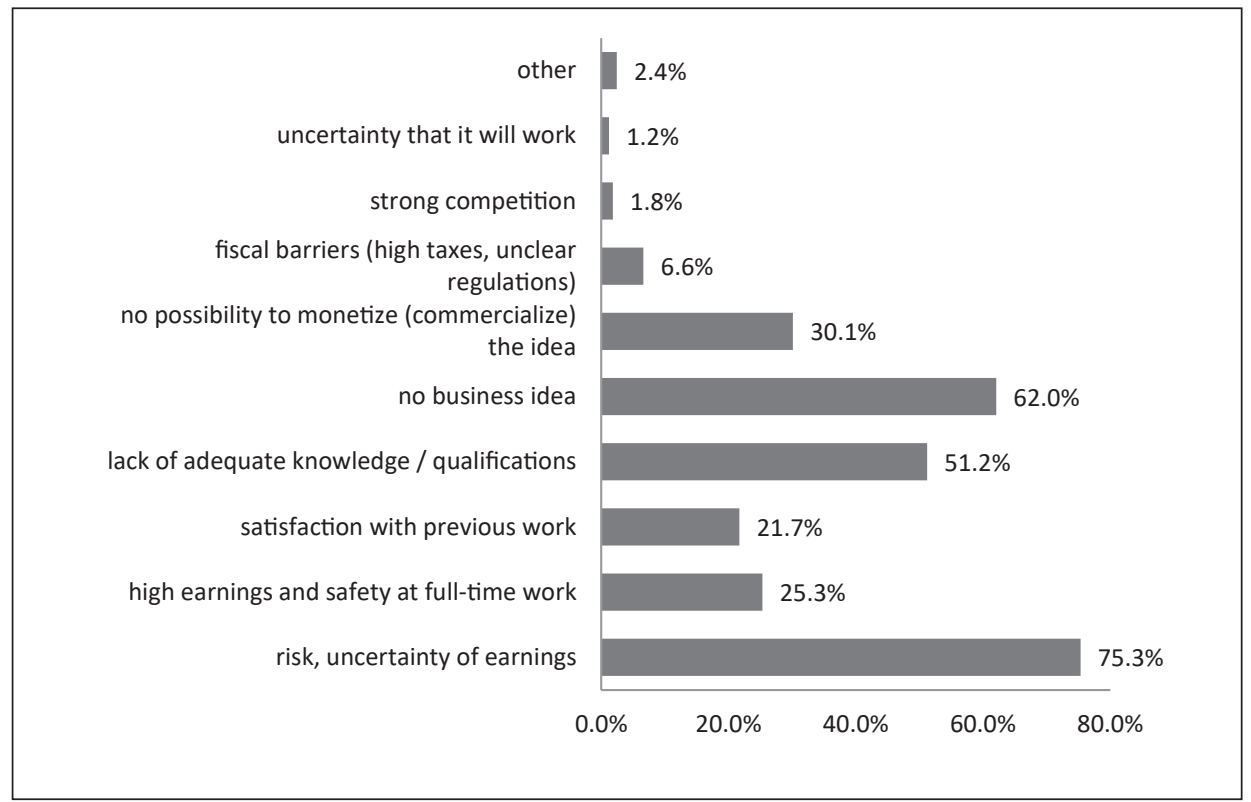

Source: author

Figure 5. Reasons for people in the IT industry succeeding in business, according to the surveyed studentsdents in the IT industry in Poland

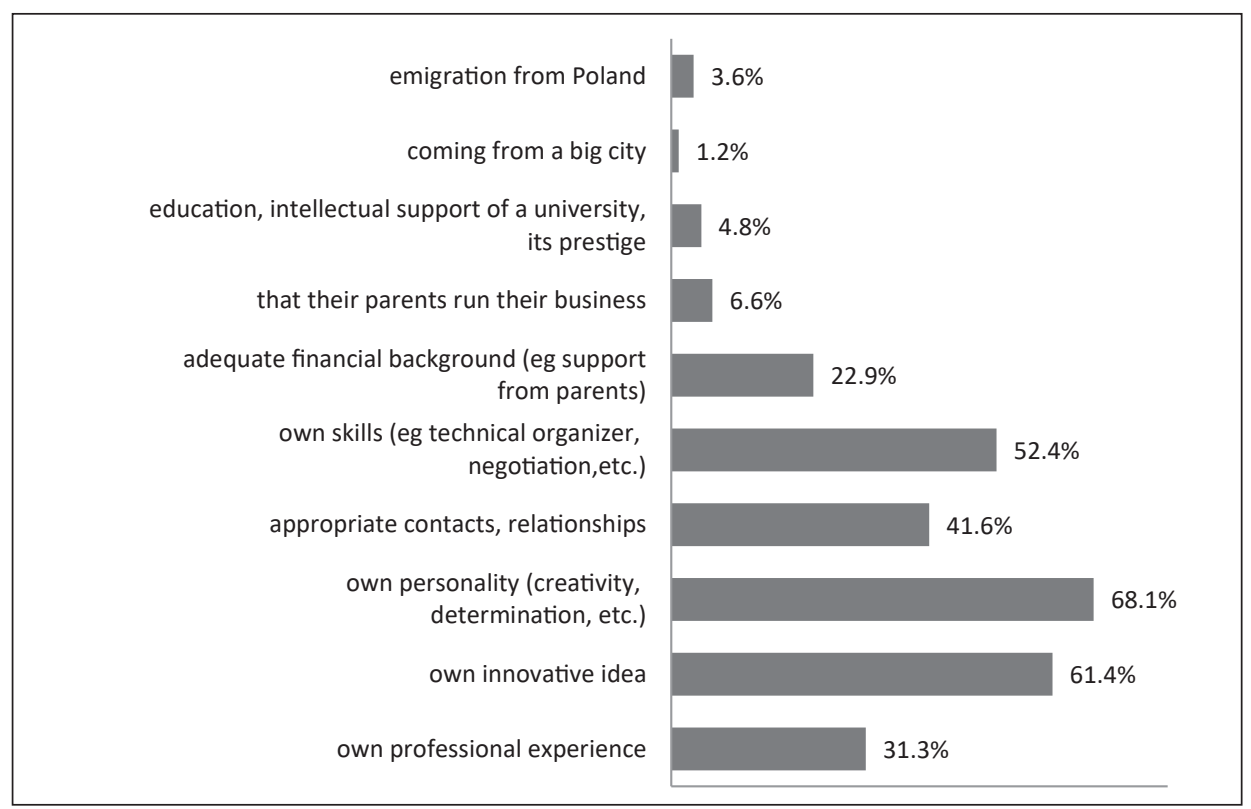

Source: author 
Figure 6. The main reasons for failures of start-ups in the IT sector in Poland, according to the surveyed students

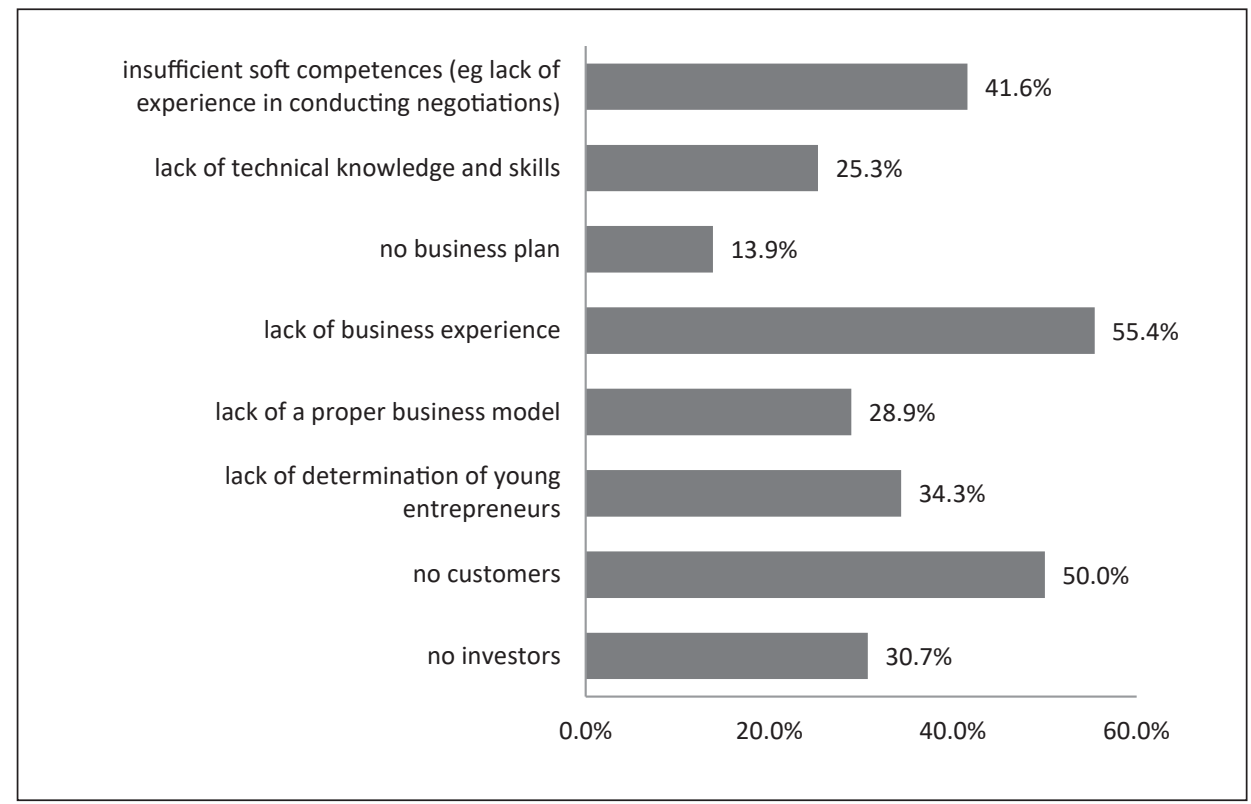

Source: author

According to the survey, the level of development of the IT industry in Poland favours the development of entrepreneurship to a significant extent (45\%). However, respondents uncertainly admit that abroad they could have a better chance of achieving business success in the IT industry than in Poland: $35 \%$ - rather yes, $12 \%$ - definitely yes. It means that the level of development of the IT sector in Poland is conducive to the development of entrepreneurship, however, the surveyed students are looking for more development opportunities abroad. An explanation of the sceptical attitude of students towards the development of a company in Poland can be found by an analysis of the index of economic freedom published every year by the Heritage Foundation (2019 Index of Economic Freedom, 2020). The economic freedom score for Poland is 67.8, which makes the Polish economy the 46th most free in the 2019 Index. Compared to the previous year, Poland's overall score had decreased by 0.7 of a point, with a plunge in the score for judicial effectiveness not fully offset by improvements in investment freedom and fiscal health. In the Europe region, Poland is ranked 23rd among 44 countries and its overall score is below the regional average (however above the world average). "Poland's positive economic reputation was earned through structural reforms: trade liberalization, low taxes, and business-friendly regulations. Enthusiasm for reform has waned in recent years amid political and policy uncertainty that has contributed to currency volatility and weakened rates of investment. Challenges include deficiencies in road and rail infrastructure, a rigid labour code, a weak commercial court system, government red tape, and a burdensome tax system for entrepreneurs. Reforms are also needed to buttress the independence of the judiciary and reduce opportunities for corruption" (2019 Index of Economic Freedom, 2020). These data clearly show that running a company in Poland is hindered by many 
Figure 7 . The three biggest advantages of running own business in the IT industry according to the surveyed students

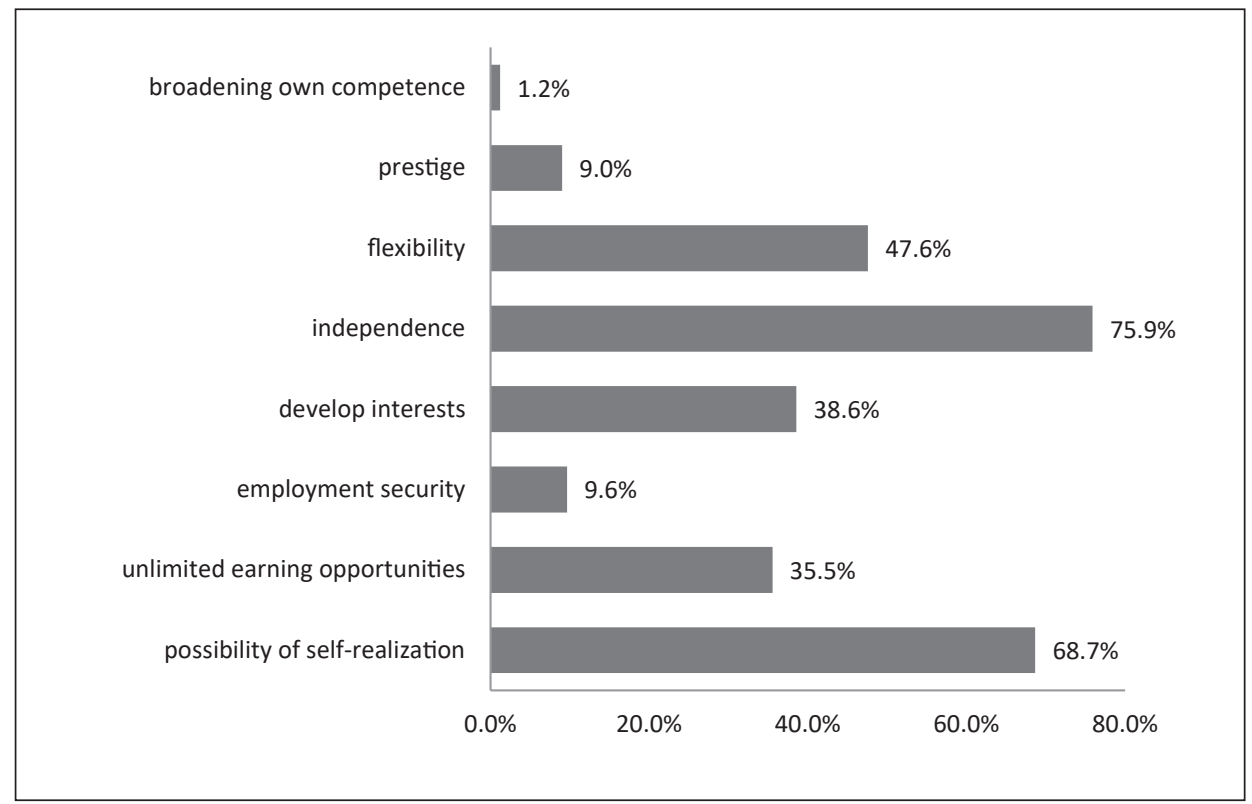

Source: author

Figure 8. The three most important opportunities for entrepreneurship development among students in the IT industry, according to the surveyed students

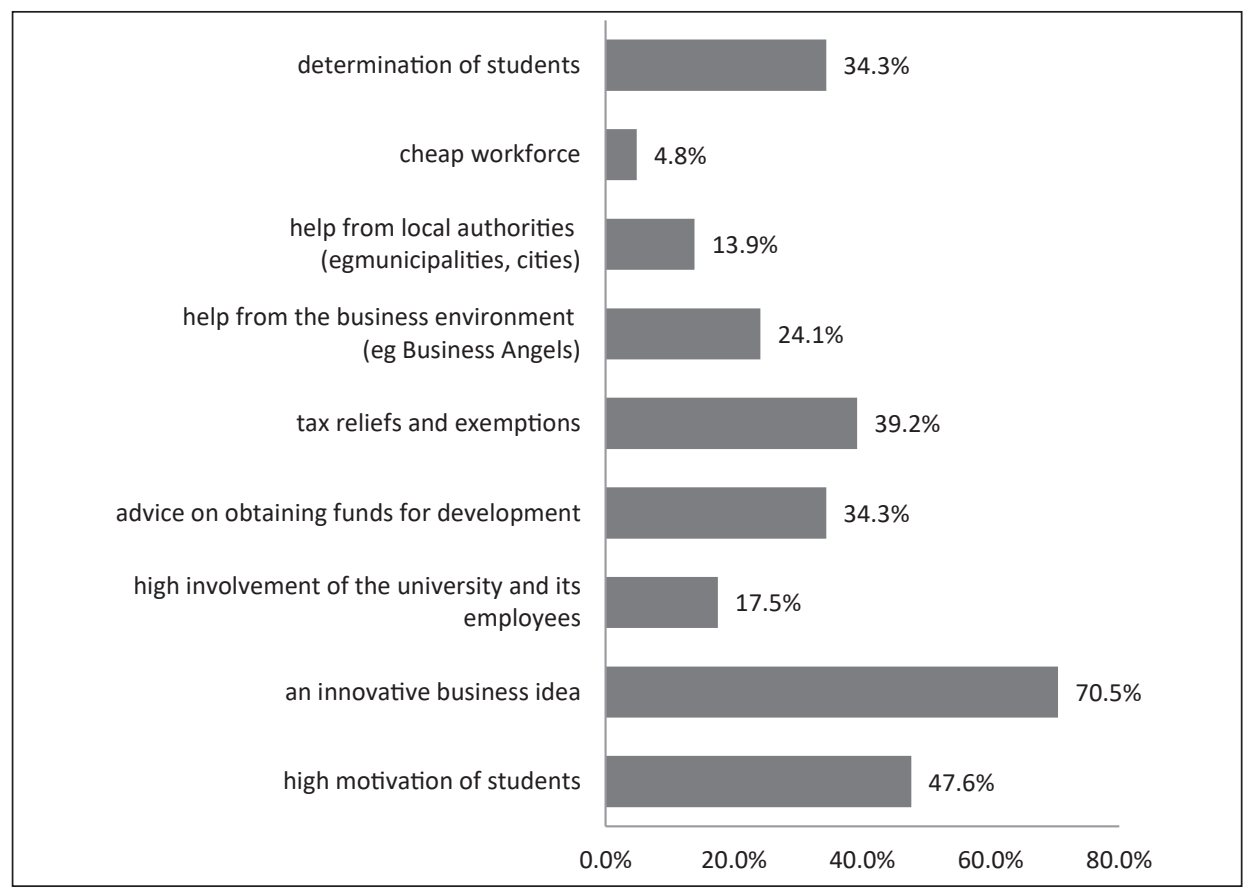

Source: author 
Figure 9. The three largest barriers to the development of entrepreneurship among students in the IT industry in Poland, according to the surveyed students

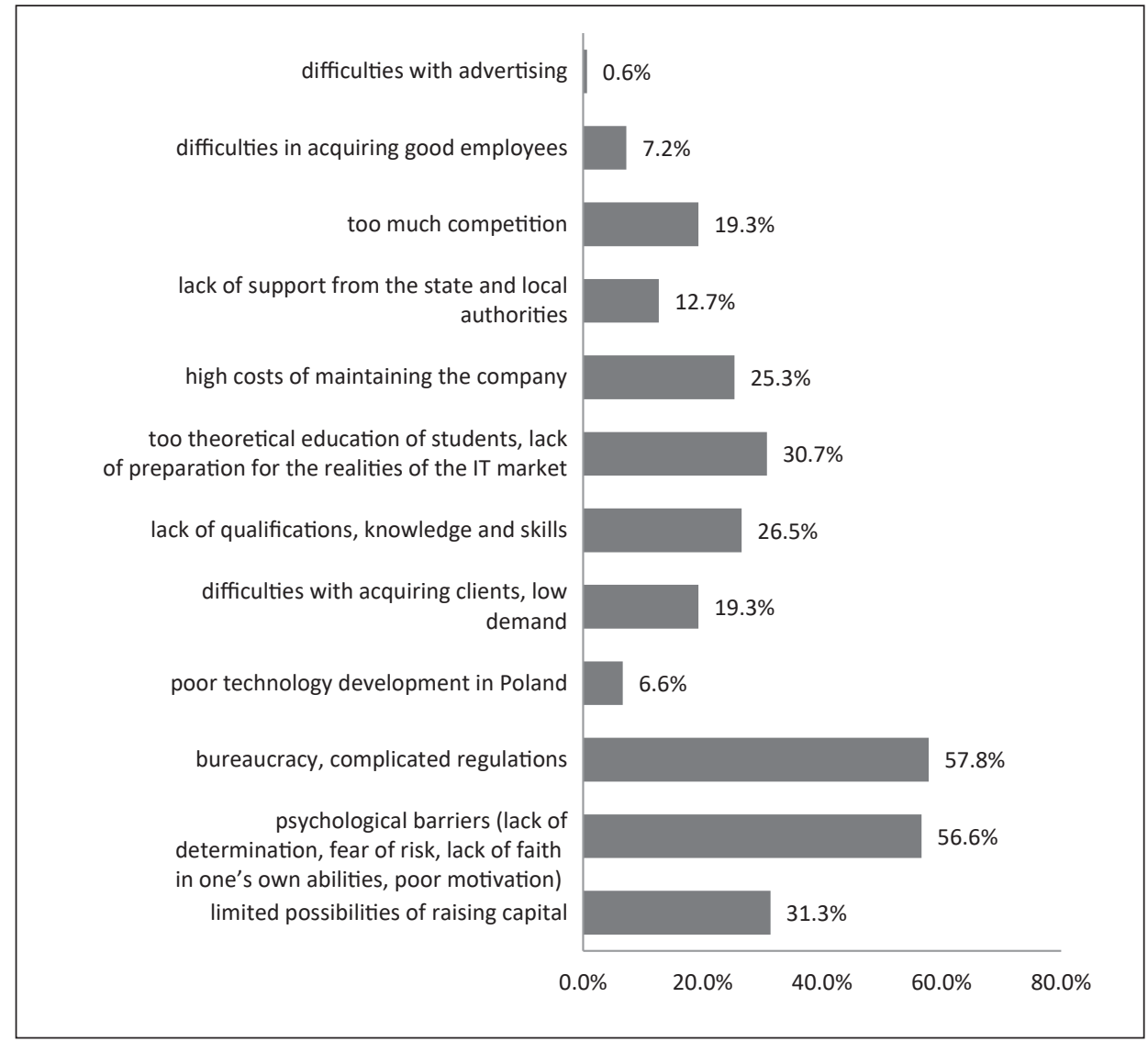

Source: author

political and legal as well as fiscal factors. No wonder then that students see a greater chance of success of their business abroad.

Before starting their own business in the IT industry, students may also be held back by the prospect of achieving high earnings in a full-time job. Research has shown that, according to $47 \%$ of respondents, the relatively high earnings in the IT industry offered in full-time work may significantly discourage young people from starting their own business activity.

The consolation, however, can be the information about what benefits, according to IT students, are associated with self-employment. For the respondents, running their own businesses means primarily independence (76\%), self-fulfilment (69\%) and flexibility (48\%) (Figure 7). These are the reasons why, according to the respondents, it is worth setting up their own companies. Therefore, the factor encouraging starting a business may be the opportunity to decide for themselves and their development.

The most important opportunities for entrepreneurship development among students in the IT industry are seen in an innovative business idea (71\%), high motivation 
(48\%) and student determination (34\%), tax allowances and exemptions (39\%), as well as help in obtaining development funds (34\%) (Figure 8). Therefore, students mainly need the right motivation and a business idea which are the basic opportunities when it comes to running their own companies in the IT industry.

In turn, the most important barriers to entrepreneurship development among students in the IT industry are bureaucratisation in the field of running a company (58\%), as well as psychological barriers (lack of determination, fear of risk, lack of faith in abilities) (57\%). The barrier of raising capital is a big barrier (31\%). Many students also point to too much theoretical education and the lack of preparation for the realities of the IT market (31\%) (Figure 9).

Barriers related to the political, legal and fiscal situation are indeed high, as mentioned above when analyzing the Index of Economic Freedom. Students seem to be aware of them, but, in addition, they point to other important aspects that seem to remain in the hands of entrepreneurship teachers. In the questionnaires, students emphasized the importance of practical workshops in running their own businesses as well as developing a marketing strategy. They have many ideas, however, they cannot sell them properly. They do not know how to acquire new customers, they lack negotiation skills. Practical classes involving the development of business plans would be very desirable, including the development of marketing strategies, combined with the development of soft skills. The development of entrepreneurship among students of the IT industry is related to a large extent to soft competences and shaping the practical skills related to running a business, including marketing skills.

\section{Conclusions}

Most IT students show entrepreneurial traits; they are creative, have lots of ideas and huge potential. This is confirmed by the fact that every second student plans to open a business in the future. Most, however, are held back before establishing their own company by the risk and uncertainty of earnings. Many also think that they do not have adequate knowledge in this field or qualifications. At the same time, students are aware that success in business is achieved primarily through appropriate personality traits (i.e. creativity and determination) and an innovative idea. The main reason for start-up failure is the lack of business experience and a deficiency in soft skills. The level of development of the IT industry in Poland is conducive to the development of entrepreneurship, however the surveyed students see higher development opportunities abroad. One barrier to the development is the relatively high earnings in the IT industry offered in full-time work which can greatly discourage young people from starting their own business. The most important opportunities are innovative business ideas and high motivation and determination. The most important barriers however are bureaucratization in the field of running a business, as well as psychological (lack of determination). Thus, the development of entrepreneurship is largely associated with soft competences and the shaping of the practical skills related to running a business, including marketing skills.

Students of the IT industry show many entrepreneurial features. The basic educational challenges in shaping the entrepreneurship of these students include shaping soft skills as well as practical skills related to running a company. Research has shown that on IT courses, the importance of shaping soft competences, which are necessary for running 
a business, is largely omitted. They should build confidence, which is very important for people who would like to start their business but are afraid of failure, and it is the main barrier to entrepreneurship development in the IT industry. Creative activities that stimulate business ideas also play an important role in educating the entrepreneurship of IT students. Undoubtedly, the future may be the use of gamification in the entrepreneurial education of IT students, so that they could learn hard and soft skills at the same time.

\section{References}

2019 Index of Economic Freedom. Poland (2020, March 10). Retrieved from: https://www.heritage.org/ index/country/poland

Bellotti, F., Berta, R., De Gloria, A., Lavagnino, E., Dagnino, F., Ott, M., Mayer, I.S. (2012). Designing a course for stimulating entrepreneurship in higher education through serious games. Procedia Computer Science, 15, 174-186.

Bellotti, F., Berta, R., De Gloria, A., Lavagnino, E., Antonaci, A., Dagnino, F. M., Ott, M. (2013, July). A gamified short course for promoting entrepreneurship among ICT engineering students. In 2013 IEEE 13th International Conference on Advanced Learning Technologies. IEEE.

Henry, C., Hill, F., Leitch, C. (2005). Entrepreneurship education and training: can entrepreneurship be taught? Part I. Education+ Training, 47(2), 98-111.

Higgins, D., Elliott, C. (2011). Learning to make sense: what works in entrepreneurial education?. Journal of European Industrial Training, 35(4), 345-367.

Infuture Hatalska Foresight Institute. (2019). Pracownik przyszłości. Pozyskano z: http://infuture.institute/raporty/pracownik-przyszlosci/

Kuratko, D.F. (2005). The emergence of entrepreneurship education: Development, trends, and challenges. Entrepreneurship theory and practice, 29(5), 577-597.

La Guardia, D., Gentile, M., Dal Grande, V., Ottaviano, S., Allegra, M. (2014). A game based learning model for entrepreneurship education. Procedia-Social and Behavioral Sciences, 141, 195-199.

Lüthje, C., Franke, N. (2003). The 'making' of an entrepreneur: testing a model of entrepreneurial intent among engineering students at MIT. R \& D Management, 33(2), 135-147.

Milczarski, P. (2015). Teaching Entrepreneurship IT Students in Poland and Chosen EU Countries. Przedsiębiorczość i Zarzadzanie, 16(6/2), 75-88.

Niedźwiedziński, M., Klepacz, H., Szymańska, K. (2016). Wspieranie przedsiębiorczości akademickiej w branży informatycznej a przemiany na rynku pracy. Przedsiębiorczość i Zarzadzanie, 17(4/1), 355-366.

Oosterbeek, H., Van Praag, M., Ijsselstein, A. (2010). The impact of entrepreneurship education on entrepreneurship skills and motivation. European Economic Review, 54(3), 442-454.

Peterman, N.E., Kennedy, J. (2003). Enterprise education: Influencing students' perceptions of entrepreneurship. Entrepreneurship Theory and Practice, 28(2), 129-144.

Rasmussen, E.A., Sørheim, R. (2006). Action-based entrepreneurship education. Technovation, 26(2), 185-194.

Soares, F.O., Sepúlveda, M.J., Monteiro, S., Lima, R.M., Dinis-Carvalho, J. (2013). An integrated project of entrepreneurship and innovation in engineering education. Mechatronics, 23(8), 987-996.

Souitaris, V., Zerbinati, S. and Al-Laham, A. (2007). Do entrepreneurship programmes raise entrepreneurial intention of science and engineering students? The effect of learning, inspiration and resources. Journal of Business Venturing, 22(4), pp. 566-591.

Vesper, K. H., Gartner, W. B. (1997). Measuring progress in entrepreneurship education. Journal of Business Venturing, 12(5), 403-421. 
Wilson, F., Kickul, J., Marlino, D. (2007). Gender, Entrepreneurial Self-Efficacy, and Entrepreneurial Career Intentions: Implications for Entrepreneurship Education. Entrepreneurship Theory and Practice, 31(3), 387-406.

Iwona Lupa-Wójcik, PhD, Institute of Law, Administration and Economics, Pedagogical University of Krakow. Doctor of economics in the discipline of management sciences, assistant professor at the Institute of Law, Administration and Economics, Pedagogical University of Krakow. Has many years of experience as an entrepreneur and entrepreneurial trainer. Her research interests include social media in marketing and management, entrepreneurship, marketing strategic management, as well as cooperation economics and sharing economy.

ORCID: https://orcid.org/0000-0003-1673-7077

\section{Address:}

Uniwersytet Pedagogiczny im. Komisji Edukacji Narodowej w Krakowie

Instytut Prawa, Administracji i Ekonomii

ul. Podchorążych 2

30-084 Kraków, Poland

e-mail: iwona.lupa-wojcik@up.krakow.pl 